\title{
Duty Hours: More Rest? More Sleep? Less Learning?
}

\author{
Enrique Gomez-Pomar* \\ Department of Pediatrics, University of Kentucky, USA
}

Submission: February 07, 2017; Published: April 11, 2017

*Corresponding author: Enrique Gomez, Department of Pediatrics, University of Kentucky, USA, ORCID ID: orcid.org/0000-0002-5815-100X, Tel: 973-830-0057; Email: Enrique.gomez@uky.edu

Keywords: Duty hours; ACGME

\section{Short Communication}

Residency duty hours have been a source of controversy since its inception.There is a delicate balance between providing residents with adequate patient exposure to gain clinical skills and confidence; while providing ample time for uninterrupted rest and learning. If this relationship is not carefully managed,excessive clinical time can lead to fatigue, thereby compromising learning and patient safety. However, limiting patient interaction too much can have equally negative effects. Since the revision of duty hours in 2011 this topic has generated more controversy related to decreased patient interaction and continuity of care, without improvement in patient safety, resident fatigue, and or resident learning.

The designation of "resident" refers back to the initial days of post-graduate medical education, when newly minted physicians would literally reside in the hospital; often working continuously for several days without rest [1]. In 1910 the American Medical Association (AMA) published the first list of approved residency programs [1]. Forty years later, Internal Medicine and General Surgery specialties created the Resident Review Committees (RRCs) to serve as independent reviewers with logistical support from the AMA [1]. The Liaison Committee for Graduate Medical Education (LCGME), created in 1972, assumed control of the RRCs and would later become the current American Council on Graduate Medical Education (ACGME) in 1981 [1].

True increase in supervision of resident physicians came about in 1984 after the death of Libby Zion, a patient in a New York Emergency Department who was cared for by fatigued residents [1]. A review of the case showed that the patient likely died from serotonin syndrome after two antipsychotic drugs were administered too close together, presumably as a result of fatigued physicians. This led to the creation of the Bell Commission which recommended, in 1987, to limit patient contact for resident physicians to eighty hours per week, with a maximum of twenty four continuous work hours. It also required the attending physicians to be present in hospitals at all times [1]. While improvements were being made in New York, these changes were generally ignored by the rest of the nation until 2003. In that year, the ACGME adopted the recommendations for all programs, with the additional requirements of the following:

A. One day free of duty each week.

B. A limit of thirty hours of consecutive duty.

C. Hospital call no more frequent than every third night.

These standards remained in place until 2011 when the AGCME voted to further limit duty hours by capping the number of consecutive working hours to sixteen for interns and twenty eight for senior residents. With the implementation of new regulations, training programs feared that further reduction in work hours would negatively affect resident's education. In response, the ACGME task force committee released a statement supporting the sixteen-hour standard for first-year residents indicating that these new regulations governing interns would increase the amount of direct supervision of residents, promoting patient safety and resident learning. The committee also stated that supervision is likely to be the most important factor to prevent errors [2].

The main reason for regulation and implementation of duty hours was the concern for patient safety and resident's well being. The prevailing theory is that fatigued residents have an increased propensity to make medical errors compared to their rested colleagues. The main debate comes from the question of who provides safer care, a well-rested resident who only knows the patient from a hand-off or a fatigued resident who has cared for the patient since admission. Before the 2011 change, studies showed that limiting resident work hours would not fix sleep 
deprivation and thus would not reduce errors [3,4,5]. In some cases, limiting resident daily work hours can increase harm to patients and resident fatigue, by compressing the time in which residents have to complete their work and by an increase in the number of hand-offs with a decrease in continuity of care [3-5].

After the 2011 change in regulations, studies have shown conflicting results with some showing improved quality of life and increased sleep; while others show that there was no change in sleep time, depressive symptoms, or well-being [5,6]. Additionally, an unintended consequence of the 2011 changes was a decrease in the quality of life for senior residents. Resident wellness has decreased due to an increased stress while working and a decrease in professionalism. This decrease stems from shifting the focus of residency from the needs of patients to the need to comply with duty hours, thus decreasing a resident's ownership of patient care and accountability. Despite the newly implemented changes, it appears that the expected gains in resident wellness have not materialized.

Another major concern with limiting duty hours is the impact on resident education and medical knowledge. Currently, there is very little data from non-surgical specialties about the effect of shortened duty hours on a resident's readiness to practice independently. In a study comparing two groups of senior residents, with one group following the 2003 duty hour's recommendation and the other adopting the 2011 guidelines, patient mortality, readmission rate, and length of stay were unchanged [7]. However, residents reported that they had more periods with less than 10 hours off between shifts, decreased attendance to teaching sessions, and felt less prepared to crosscover patients [8]. There is also an increase concern of decrease exposure to surgical procedures with the new regulations. A longitudinal study of 213 surgical interns found an overwhelming decrease in the perception of continuity of care, coordination of care, and practice-based learning [9]. Additionally, there was no change in the quality of life or decrease in fatigue $[9,10]$.

Regarding certifying examinations, a recent study found that there was no decrease in the Internal Medicine Board pass rates following the 2003 duty hour reform [11]. There was also no change in the surgical pass rates after the 2011 duty hour's changes [12] nor did the Pediatrics boards first time takers pass rates from 2011 to 2015 [13]. However, a 2014 systematic review of the literature for surgical residents showed worsening in education in $86 \%$ of the studies reviewed with no changes in the remaining 14\% [6]. This is supported by a 2015 review that included 27 studies and found a negative impact of the 2011 regulations on resident's education in $67 \%$ of the studies.

Residency fatigue is a serious problem that needs to be addressed and prevented. The common perception that excessive work hours are the main component of resident fatigue is flawed as there are many other factors that come into consideration [2,5]. It seems that the objective of the 2011 change in duty hours regulation has failed since it has resulted in:
A. Adecrease in residenteducation, confidence, accountability, and continuity of care.

B. No real improvement in patient care, well-being of the resident and fatigue levels. Further reduction in working hours will not result in improvement of patient safety, medical knowledge, or resident well-being [3,6,9].

Duty hours are important and they should be respected, however, it seems that there is an impending need for a reevaluation of the current practices and the evidence available in order to modify the current regulations. Any further change that limits resident interaction with patients should be carefully examined, especially for the unintended consequences on patient care, resident learning, and wellbeing.

\section{References}

1. Philibert I, Taradejna, Cynthia (2011) The ACGME 2011 Duty Hour Standard Enhancing Quality of Care, Supervision and Resident Professional Development. Chapter 2: A Brief History of Duty Hours and Resident Education, pp. 5-11.

2. ACGME (2015) Force on Quality Care and Professionalism Response to Public Comments.

3. Fletcher, Kathlyn E, Davis, Stephen Q, Underwood W, et al. (2004) Systematic Review: Effects of Resident Work Hours on Patient Safety. Annals of Internal Medicine 141: 851-857.

4. Baldwin DC, Daugherty SR (2004) Sleep Deprivation and Fatigue in Residency Training: Results of a National Survey of First- and SecondYear Residents. Sleep 27 (2): 217-223.

5. Roisin O, Christopher SP (2014) Delinking resident duty hours from patient safety. BMC Medical Education 14(Suppl 1): S2.

6. Ahmed N, Devitt KS, Keshet I, Spicer J, Imrie K (2014) A Systematic Review of the Effects of Resident Duty Hour Restrictions in Surgery Impact on Resident Wellness, Training, and Patient Outcomes. Ann Surg 259(6): 1041-1053.

7. Auger KA, Landrigan CP, Gonzalez del Rey JA, Seipling KR, Schuarew HJ, et al. (2012) Better Rested, but More Stressed? Evidence of the Effects of Resident Work Hour Restrictions. Acad Pediatr 12(4): 335-343.

8. McCoy CP, Andrew JH, Conor GL, McDonald S, Amy SO (2011) Effect of 16-Hour Duty Periods on Patient Care and Resident Education. Mayo Clin Proc 86(3): 192-196.

9. Antiel RM, Reed DA, Van Arendonk KJ, Wightman SC, Hall DE, et al. (2013) Effects of Duty Hour Restrictions on Core Competencies, Education, Quality of Life, and Burnout Among General Surgery Interns. JAMA Surg 148(5): 448-455.

10. Bolster L, Rourke L (2015) The Effect of Restricting Residents Duty Hours on Patient Safety, Resident Well-Being, and Resident Education: An Updated Systematic Review. J Grad Med Educ 7(3): 349-363.

11. Jeffrey HS, Patrick SR, Kamal MF, Amy KR, Dylan S (2014) Assessing the Effects of the 2003 Resident Duty Hours Reform on Internal Medicine Board Scores. Academic Medicine 89(4): 644-651.

12. Rajaram R, Chung JW, Jones AT, Cohen ME, Dahlke AR, et al. (2014) Association of the 2011 ACGME Resident Duty Hour Reform With General Surgery Patient Outcomes and With Resident Examination Performance. JAMA 312(22): 2374-2384.

13. ABPorg (2017) Initial Certification and Maintenance of Certification Exam Pass Rates. 


\section{Your next submission with Juniper Publishers} will reach you the below assets

- Quality Editorial service

- Swift Peer Review

- Reprints availability

- E-prints Service

- Manuscript Podcast for convenient understanding

- Global attainment for your research

- Manuscript accessibility in different formats ( Pdf, E-pub, Full Text, Audio)

- Unceasing customer service

Track the below URL for one-step submission https://juniperpublishers.com/online-submission.php 